\title{
The Effect of Heating Time and Heating Temperatures to Layer Thickness and The Glossiness Level of A Surface in Blackening Coating Process
}

\author{
Arya Mahendra Sakti, Aisyah Endah Palupi, Dyah Riandadari
}

\begin{abstract}
Metal coating without electrical energy using usually could be the conversion coating technique. One method of the conversion coatings that are widely used in the industrial field is blackening or black oxide coating. Blackening or black oxide coating technique is a chemical conversion process that is formed from the chemical reaction between the iron in ferrous metals by an oxidizing salt to form a layer of magnetite $\left(\mathrm{Fe}_{3} \mathrm{O}_{4}\right)$ thin metal substrates. The metal coating process has a lot of choices to improve the quality of materials from metallic and nonmetallic. This study aims to investigate the effect of the time and the temperature of the heating process of the steel AISI 1015 on the thickness and the value of the glossiness level by the blackening processing technique. The research variables are used various heating process time: $30 ; 60$; and 90 minutes, temperature: $100{ }^{\circ} \mathrm{C} ; 150^{\circ} \mathrm{C}$ and $200^{\circ} \mathrm{C}$, and other variables are controlled constantly. The workpieces made from a steel metal plate AISI 1015 has a dimension size $=200 \times 30 \times 3 \mathrm{~mm}^{3}$ in 27 pieces. The experimental method was designed by formation $3 x$ $3 x 3$. It could be revealed the longer the healing process time could increase the thickness of the layer of the workpiece surface. A higher heating temperature could decrease the value of the glossiness level of a metal surface. The surface layer thickness level is found the best in the plating process time about 90 minutes and a temperature of $200^{\circ} \mathrm{C}$ with a coating thickness

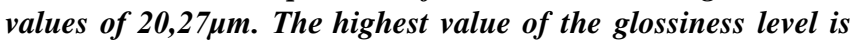
obtained at the highest coating time of 30 minutes at a temperature of $100^{\circ} \mathrm{C}$ with the value of the shiny level of about $68.50 \mathrm{GU}$.
\end{abstract}

Keywords: blackening technique, layer thickness, and glossiness level.

\section{INTRODUCTION}

A metal coating is a metal layer deposition process on the electrode aimed at forming a surface with properties or dimensions different from the original metals [1]. A metal coating is one way to tackle the damage caused by corrosion on the metal and also serves as a resistance to the original material. Besides, plating also provides an aesthetic value of

Revised Manuscript Received on January 15, 2020.

* Correspondence Author

Arya Mahendra Sakti, Department of Mechanical Engineering FT-Unesa, Surabaya, Indonesia. Email: E-mail: aryamahendra@unesa.ac.id

Aisyah Endah Palupi, Department of Mechanical Engineering FT-Unesa, Surabaya, Indonesia. Email: aisyahpalupi@unesa.ac.id

Dyah Riandadari, Department of Mechanical Engineering FT-Unesa, Surabaya, Indonesia. Email: dyahriandadari@unesa.ac.id the metal to be coated, for example, color and texture, as well as to reduce the resistance of contacts and increase surface conductivity or reflectivity. Metal coating without the use of electrical energy usually called the conversion coating. Conversion coating is a coating method that utilizes a chemical reaction to form a protective layer on the metal surface. Conversion coatings can be divided into two groups: natural and chemical conversion coating. Natural conversion coating commonly called a natural oxide layer formed on a metal substrate, where as the chemical conversion coating is an artificial oxide layer formed on the metal substrate of the results of immersion in liquid chemicals [2,8,9]. In the industrial world, the metal is the dominant material used for components and machine tool supporting the engine. Among these materials, is a material widely used in engine components, which in practice is only done using a lubricating oil to inhibit corrosion rate due to the nature of the components that have high dimensional tolerances and require coatings that do not add significantly dimensional objects. One form of conversion coating is blackening or black oxide coating. Blackening or black oxide coating is a chemical conversion process that is formed from the reaction between the iron in ferrous metals by oxidizing salt. Blackening/black oxide coating used increasingly popular for durability against corrosion and aesthetic results without changing the dimensions of an object. Blackening coating occurs when the Fe atoms that exist on the steel surface reacts to form magnetite $\left(\mathrm{Fe}_{3} \mathrm{O}_{4}\right)$. Surfaces cleaned product in alkaline soak and then rinse before soaking in a solution of blackening. After the second rinse, the final result will be covered by rust prevention, which can produce the final shape that varies from slightly oil until firm and dry $[3,7,10]$. The material used in a study is also affected by the heating temperature. The material will show that the thickness of the oxide layer on the steel AISI 304 increased from $8 \mathrm{~nm}$ at a temperature of $150^{\circ} \mathrm{C}$ to about $30 \mathrm{~nm}$ at a temperature of $450^{\circ} \mathrm{C}$ [4]. The black oxide coating process is determined by the optimum operating conditions and proper, for example, by determining the length of time of 150 seconds immersion and become stable after passing 180 seconds, the heating temperature $85^{\circ} \mathrm{C}$. Existing operating conditions will affect the surface roughness numbers increased from 180 $\mathrm{nm}$ to about $290 \mathrm{~nm}$, and also

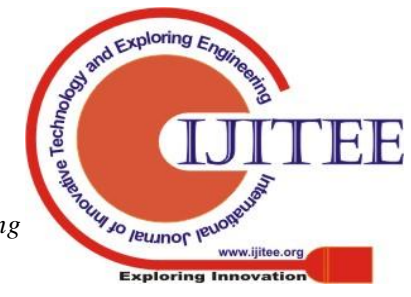



Surface in Blackening Coating Process

on the thickness of the copper material surfaces [5]. The heating time in the process of cast iron blackening effect on the thickness of the oxide layer, the oxide layer thickness on cast iron increased from $0.4 \mu \mathrm{m}$ to $1.2 \mu \mathrm{m}$ in 30 minutes heating time and temperature $145^{\circ} \mathrm{C}$ [2].

This study aims to determine the thickness of the surface layer and the gloss layer of the workpiece surface black oxide coating results.

\section{MATERIAL AND METHODS}

\section{A. Material}

In this research, we used metal-coated AISI 1015 steel. The chemical composition of AISI 1015 steel (5\% wt): 0.15C, 0.082Mn, $0166 \mathrm{Si}, 0.054 \mathrm{P}, 0.15 \mathrm{~S}$, and Bal. Fe $[11,12]$. In this experiment, the workpiece in the form of steel plates AISI 1015 form. Dimensions specimens plate has a length of $200 \mathrm{~mm}$, width $20 \mathrm{~mm}$, and $3 \mathrm{~mm}$ thick.

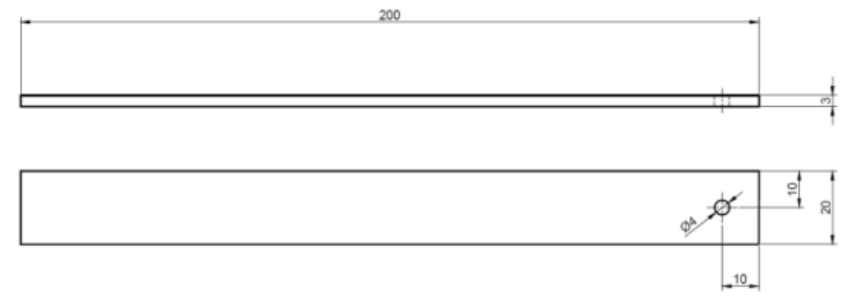

Fig. 1. Specimen Shape Plat

\section{B. Methods}

The experimental design used was a factorial design $3 \times 3 \times 3$ fixed-effect model. The response variable in this study is the layer thickness of the workpiece and the workpiece gloss layer of black oxide coating results [14]. As the independent variable is the time of heating and the heating temperature. There are 3 levels of heating time, namely: 30; 60; and 90 minutes. The heating temperature also has three levels, namely $100^{\circ} \mathrm{C} ; 150^{\circ} \mathrm{C}$ and $200^{\circ} \mathrm{C}$, other variables are held constant. The control variable is the type of workpiece, a saline solution used was a mixture of $30 \%$ sodium hydroxide $(\mathrm{NaOH}), 10 \%$ sodium nitrate $\left(\mathrm{NaNO}_{3}\right), 10 \%$ Sodium Nitrite $\left(\mathrm{NaNO}_{2}\right), 50 \%$ distilled $\left(\mathrm{H}_{2} \mathrm{O}\right)$ [6,13]. The randomized experiment with three replications. Thus obtained 27 observation to experiment. The procedure begins with the preparation of a research workpiece by size $200 \mathrm{~mm}$ x $20 \mathrm{~mm}$ x $3 \mathrm{~mm}$, Puncture specimens with a diameter of $4 \mathrm{~mm}$, and clean the workpiece by means of polished. Clean the specimen before the blackening process by dipping the specimen into the ethanol solution. Preparation of salt solution, by mixing $30 \%$ sodium hydroxide $(\mathrm{NaOH}), 10 \%$ sodium nitrate $\left(\mathrm{NaNO}_{3}\right)$, and $10 \%$ Sodium Nitrite $\left(\mathrm{NaNO}_{2}\right)$ into $50 \%$ distilled $\left(\mathrm{H}_{2} \mathrm{O}\right)$. Once well mixed, heated saline solution using the stove and keep the temperature steady $100^{\circ} \mathrm{C}, 150^{\circ} \mathrm{C}$, and $200^{\circ} \mathrm{C}$. Coating specimens by preparing a specimen that has been cleaned and is associated with a holder with wire so that the position of the specimen hangs in the plating bath. Specimen numbered 27 pieces that had been prepared coating process is then performed at a temperature of $100^{\circ} \mathrm{C}, 150^{\circ} \mathrm{C}$, and $200^{\circ} \mathrm{C}$ with a variation of 30 minutes, 60 minutes and 90 minutes. After the coating process is completed, the specimens are dried and then soaked in the oil. After the specimen is completed the coating process, then proceed with the entire specimen coating thickness measurement using an ultrasonic thickness gauge. Followed by entire specimen surface gloss measurements using a gloss meter.

\section{RESULT AND DISCUSSION}

\section{A. Layer Thickness Testing}

Coating thickness measurement test specimens after blackening coating process, the coating thickness results are as follows Table 1 below. After the layer thickness test data is obtained, the results obtained are made in graphical form as can be seen in Figures 2 to 4 .

TABLe 1. THE TeST DATA LAYER THICKNESS OF THE WORKPIECE

\begin{tabular}{|c|c|c|c|c|c|c|}
\hline \multirow[t]{2}{*}{ No. } & \multirow{2}{*}{$\begin{array}{c}\text { Time } \\
\text { (minute) }\end{array}$} & \multirow{2}{*}{$\begin{array}{c}\text { Temperatures } \\
\left({ }^{\mathrm{O}} \mathrm{C}\right)\end{array}$} & \multicolumn{3}{|c|}{ Test Thickness (GU) } & \multirow{2}{*}{$\begin{array}{c}\text { Average } \\
\text { (GU) }\end{array}$} \\
\hline & & & $\mathrm{I}$ & II & III & \\
\hline 1 & 30 & 100 & 16.52 & 16.50 & 16.48 & 16.50 \\
\hline 2 & 30 & 100 & 16.48 & 16.46 & 16.42 & 16.45 \\
\hline 3 & 30 & 100 & 16.46 & 16.44 & 16.45 & 16.45 \\
\hline 4 & 30 & 150 & 17.48 & 17.42 & 17.46 & 17.45 \\
\hline 5 & 30 & 150 & 17.46 & 17.48 & 17.44 & 17.46 \\
\hline 6 & 30 & 150 & 17.47 & 17.46 & 17.42 & 17.45 \\
\hline 7 & 30 & 200 & 18.12 & 18,14 & 18.12 & 18.13 \\
\hline 8 & 30 & 200 & 18.10 & 18.16 & 18.16 & 18,14 \\
\hline 9 & 30 & 200 & 18.16 & 18.20 & 18.18 & 18.18 \\
\hline 10 & 60 & 100 & 17.44 & 17.40 & 17.42 & 17.42 \\
\hline 11 & 60 & 100 & 17.50 & 17.44 & 17.46 & 17.47 \\
\hline 12 & 60 & 100 & 17.48 & 17.46 & 17.45 & 17.46 \\
\hline 13 & 60 & 150 & 18.36 & 18,32 & 18.34 & 18.34 \\
\hline 14 & 60 & 150 & 18.40 & 18.38 & 18.38 & 18.39 \\
\hline 15 & 60 & 150 & 18.38 & 18.36 & 18.36 & 18.37 \\
\hline 16 & 60 & 200 & 19.10 & 19.12 & 19.16 & 19.13 \\
\hline 17 & 60 & 200 & 19.14 & 19.16 & 19.12 & 19.14 \\
\hline 18 & 60 & 200 & 19.08 & 19.18 & 19.18 & 19.15 \\
\hline 19 & 90 & 100 & 18.06 & 18.10 & 18.16 & 18.11 \\
\hline 20 & 90 & 100 & 18.12 & 18,14 & 18,14 & 18.13 \\
\hline 21 & 90 & 100 & 18.18 & 18.16 & 18.15 & 18.16 \\
\hline 22 & 90 & 150 & 19.24 & 19,20 & 19.22 & 19.22 \\
\hline 23 & 90 & 150 & 19.18 & 19.22 & 19.24 & 19.21 \\
\hline 24 & 90 & 150 & 19,20 & 19.26 & 19.26 & 19.24 \\
\hline 25 & 90 & 200 & 20.27 & 20.28 & 20.26 & 20.27 \\
\hline 26 & 90 & 200 & 20.20 & 20.26 & 20.23 & 20.23 \\
\hline 27 & 90 & 200 & 20.22 & 20.25 & 20.27 & 20.25 \\
\hline
\end{tabular}

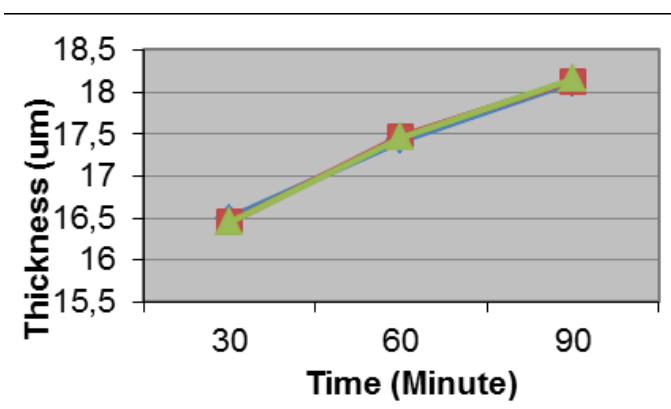

Fig. 2. Graph thickness of the metal coating results with a temperature of $100^{\circ} \mathrm{C}$ 


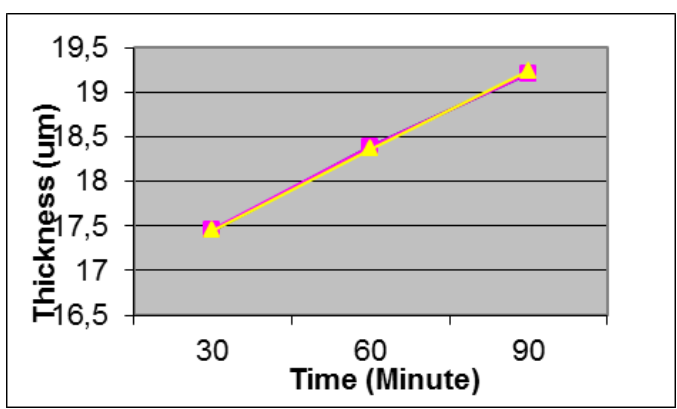

Fig. 3. Graph thickness of the metal coating results with a temperature of $150^{\circ} \mathrm{C}$

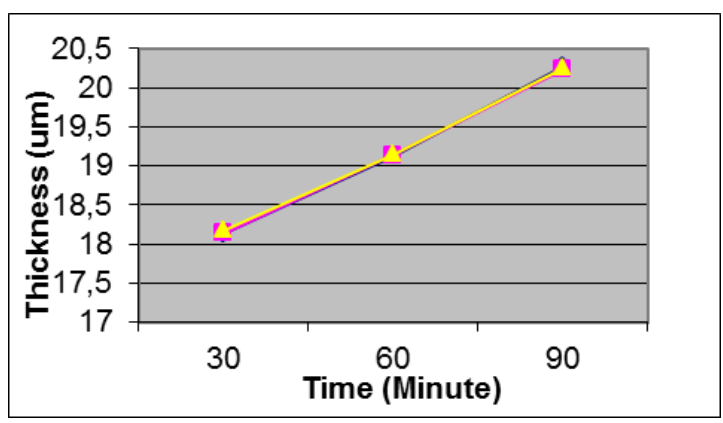

Fig. 4. Graph thickness of the metal coating results with a temperature of $200^{\circ} \mathrm{C}$

The electroplating process using blackening was affected at surface thickness value as the surface plating production. In Fig. 2 to Fig. 4 were seen the holding time that was observed at 30, 60, 90 min created the plating thickness at $16,45 \mathrm{~mm}$ to 20,27 as the highest thickness. The heating time of the blackening process affected most significant to the workpiece, that caused by the magnetic layer on the metallic surface until magnetite $\left(\mathrm{Fe}_{3} \mathrm{O}_{4}\right)$ ) formed perfectly and the color of the metallic surface was becoming darker (atomic Fe at the surface was reacted with the carbon into magnetite $\left.\left(\mathrm{Fe}_{3} \mathrm{O}_{4}\right)\right)$. At those processes, the ion $\mathrm{OH}^{-}$shifted to the surface and created diffusion-reaction on the plating surface then created the new atomic chemical bond with negative ions of $\mathrm{Fe}$ at that time become uniform thickness at the workpiece surface. That diffusion process was created and pilled up on the workpiece surface along the heating time $[15,16,19]$.

A well as the heating temperature in the blackening process that affected the metallic surface thickness, because of the high heating temperature created the diffusion-reaction of the ion $\mathrm{OH}^{-}$increased significantly and move to the metal surface. Sufficiency of ion $\mathrm{OH}^{-}$at workpiece surface that made the surface been a more alkaline condition. Then, the chemical bond reaction has been increased significantly to formed the magnetite $\left(\mathrm{Fe}_{3} \mathrm{O}_{4}\right)$ layer on the metal surface.

TABle 2. DATA FROM THE RESULTS OF GLOSS TESTING OF THE WORKPIECE LAYER

\begin{tabular}{|c|c|c|c|c|c|c|}
\hline \multirow[t]{2}{*}{ No. } & \multirow{2}{*}{$\begin{array}{c}\text { Time } \\
\text { (Minute) }\end{array}$} & \multirow{2}{*}{$\begin{array}{c}\text { Temperatures } \\
\left({ }^{\circ} \mathrm{C}\right)\end{array}$} & \multicolumn{3}{|c|}{ Test Gloss (GU) } & \multirow{2}{*}{$\begin{array}{c}\text { Average } \\
\text { (GU) }\end{array}$} \\
\hline & & & I & II & III & \\
\hline 1 & 30 & 100 & $\begin{array}{c}68.5 \\
2\end{array}$ & $\begin{array}{c}68,5 \\
0\end{array}$ & $\begin{array}{c}68.4 \\
8\end{array}$ & 68,50 \\
\hline 2 & 30 & 100 & $\begin{array}{c}68.4 \\
8 \\
\end{array}$ & $\begin{array}{c}68.4 \\
6 \\
\end{array}$ & $\begin{array}{c}68.4 \\
4 \\
\end{array}$ & 68.46 \\
\hline 3 & 30 & 100 & $\begin{array}{c}68.4 \\
4\end{array}$ & $\begin{array}{c}68.4 \\
2\end{array}$ & $\begin{array}{c}68.4 \\
5\end{array}$ & 68.44 \\
\hline 4 & 30 & 150 & 67,4 & 67.2 & 67.3 & 67.33 \\
\hline
\end{tabular}

\begin{tabular}{|c|c|c|c|c|c|c|}
\hline & & & 0 & 8 & 2 & \\
\hline 5 & 30 & 150 & $\begin{array}{c}67.3 \\
6\end{array}$ & $\begin{array}{c}67.3 \\
4\end{array}$ & $\begin{array}{c}67.2 \\
0\end{array}$ & 67.30 \\
\hline 6 & 30 & 150 & $\begin{array}{c}67.3 \\
0\end{array}$ & $\begin{array}{c}67,5 \\
0\end{array}$ & $\begin{array}{c}67.1 \\
0\end{array}$ & 67.30 \\
\hline 7 & 30 & 200 & $\begin{array}{c}66.1 \\
0 \\
\end{array}$ & $\begin{array}{c}66.4 \\
0 \\
\end{array}$ & $\begin{array}{c}66.1 \\
0 \\
\end{array}$ & 66.20 \\
\hline 8 & 30 & 200 & $\begin{array}{c}66.2 \\
4 \\
\end{array}$ & $\begin{array}{c}66.3 \\
4 \\
\end{array}$ & $\begin{array}{c}66.4 \\
0 \\
\end{array}$ & 66.33 \\
\hline 9 & 30 & 200 & $\begin{array}{c}66.2 \\
0\end{array}$ & $\begin{array}{c}66.4 \\
2\end{array}$ & $\begin{array}{c}66.3 \\
2\end{array}$ & 66.31 \\
\hline 10 & 60 & 100 & $\begin{array}{c}67.4 \\
4\end{array}$ & $\begin{array}{c}67.4 \\
6\end{array}$ & $\begin{array}{c}67.4 \\
8 \\
\end{array}$ & 67.46 \\
\hline 11 & 60 & 100 & $\begin{array}{c}67.5 \\
2\end{array}$ & $\begin{array}{c}67.4 \\
4\end{array}$ & $\begin{array}{c}67.4 \\
6\end{array}$ & 67.47 \\
\hline 12 & 60 & 100 & $\begin{array}{c}67.4 \\
6\end{array}$ & $\begin{array}{c}67.4 \\
2\end{array}$ & $\begin{array}{c}67,5 \\
0\end{array}$ & 67.46 \\
\hline 13 & 60 & 150 & $\begin{array}{c}65.2 \\
5\end{array}$ & $\begin{array}{c}65.2 \\
0\end{array}$ & $\begin{array}{c}65.1 \\
2 \\
\end{array}$ & 65.19 \\
\hline 14 & 60 & 150 & $\begin{array}{c}65.1 \\
5\end{array}$ & $\begin{array}{c}65.4 \\
0\end{array}$ & $\begin{array}{c}65.2 \\
3\end{array}$ & 65.26 \\
\hline 15 & 60 & 150 & $\begin{array}{c}65.1 \\
0 \\
\end{array}$ & $\begin{array}{c}65.1 \\
0\end{array}$ & $\begin{array}{c}65.1 \\
0\end{array}$ & 65.10 \\
\hline 16 & 60 & 200 & $\begin{array}{c}64.4 \\
0\end{array}$ & $\begin{array}{c}64.4 \\
6 \\
\end{array}$ & $\begin{array}{c}64.1 \\
0\end{array}$ & 64,32 \\
\hline 17 & 60 & 200 & $\begin{array}{c}64.3 \\
4\end{array}$ & $\begin{array}{c}64.3 \\
6\end{array}$ & $\begin{array}{c}64,2 \\
4\end{array}$ & 64.31 \\
\hline 18 & 60 & 200 & $\begin{array}{c}64.2 \\
6\end{array}$ & $\begin{array}{c}64.4 \\
5\end{array}$ & $\begin{array}{c}64.3 \\
6\end{array}$ & 64.36 \\
\hline 19 & 90 & 100 & $\begin{array}{c}66.1 \\
6\end{array}$ & $\begin{array}{c}66.1 \\
0\end{array}$ & $\begin{array}{c}66.1 \\
8 \\
\end{array}$ & 66.15 \\
\hline 20 & 90 & 100 & $\begin{array}{c}66.1 \\
2\end{array}$ & $\begin{array}{c}66.1 \\
4\end{array}$ & $\begin{array}{c}66.1 \\
5\end{array}$ & 66.14 \\
\hline 21 & 90 & 100 & $\begin{array}{c}66.1 \\
8 \\
\end{array}$ & $\begin{array}{c}66.1 \\
6 \\
\end{array}$ & $\begin{array}{c}66.1 \\
7 \\
\end{array}$ & 66.17 \\
\hline 22 & 90 & 150 & $\begin{array}{c}64.4 \\
2\end{array}$ & $\begin{array}{c}64.3 \\
0\end{array}$ & $\begin{array}{c}64,2 \\
4\end{array}$ & 64,32 \\
\hline 23 & 90 & 150 & $\begin{array}{c}64.4 \\
8\end{array}$ & $\begin{array}{c}64.4 \\
2 \\
\end{array}$ & $\begin{array}{c}64,3 \\
5 \\
\end{array}$ & 64.42 \\
\hline 24 & 90 & 150 & $\begin{array}{c}64.4 \\
6\end{array}$ & $\begin{array}{c}64.4 \\
6\end{array}$ & $\begin{array}{c}64.4 \\
2\end{array}$ & 64.45 \\
\hline 25 & 90 & 200 & $\begin{array}{c}62.6 \\
4 \\
\end{array}$ & $\begin{array}{c}62.6 \\
0\end{array}$ & $\begin{array}{c}62.7 \\
2 \\
\end{array}$ & 62.65 \\
\hline 26 & 90 & 200 & $\begin{array}{c}62.7 \\
4\end{array}$ & $\begin{array}{c}62.5 \\
6\end{array}$ & $\begin{array}{c}62.6 \\
8\end{array}$ & 62.66 \\
\hline 27 & 90 & 200 & $\begin{array}{c}62.6 \\
6\end{array}$ & $\begin{array}{c}62.6 \\
2\end{array}$ & $\begin{array}{c}62.6 \\
5\end{array}$ & 62.64 \\
\hline
\end{tabular}

\section{B. Gloss Testing}

Measurement gloss layer test specimens after blackening coating process, coating gloss results are as follows in Table 2. After taking the gloss test data, the results obtained are made in graphical form as can be seen in figure 5 to 7 below.

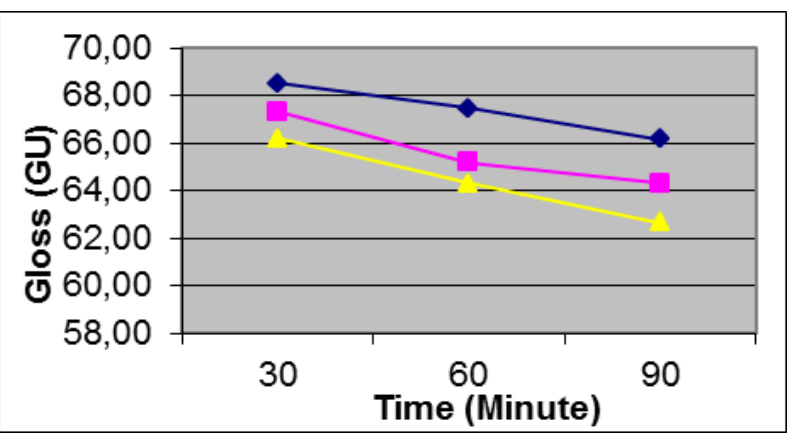

Fig. 5. Glossing of metal coating results with a temperature of $100^{\circ} \mathrm{C}$ 


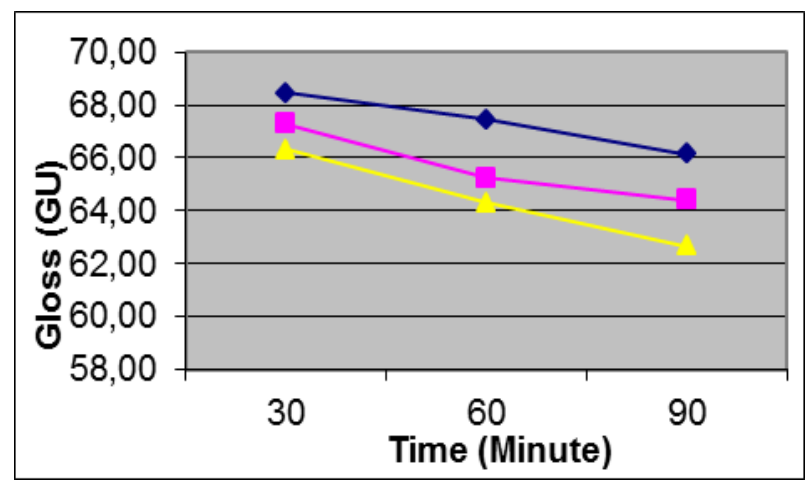

Fig. 6. Glossing of metal coating results with a temperature of $150^{\circ} \mathrm{C}$

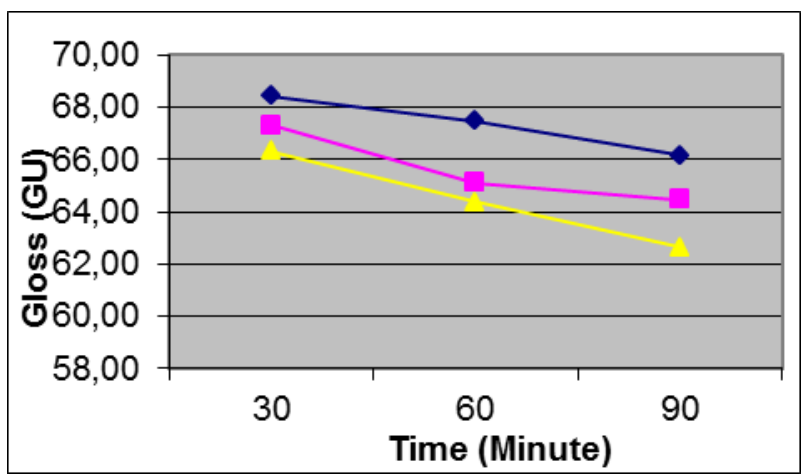

Fig. 5. Glossing of metal coating results with a temperature of $200^{\circ} \mathrm{C}$

The blackening affected to the shiny grade of the metal surface as the plating metal production. Figures 5 to 7 were shown the holding time that investigated at 100, 150, 200 min created the shiny grade level was $68,50 \mathrm{GU}$ with the lowest grade at $62,64 \mathrm{GU}$. The heating time of the blackening affected the layer thickness on the metal surface significantly. Because the heating time created the plating layer of the metal increased in the thickness obviously. Then the surface colors been darker and reduced the shiny grade level of the workpiece surface $[15,17,18]$.

The heating temperature importantly influenced increased the thickness of the metal surface. By the investigation described the higher heating temperature created an increased in the thickness of magnetite $\left(\mathrm{Fe}_{3} \mathrm{O}_{4}\right)$ on metal surface nevertheless reduced the shiny grade level.

\section{CONCLUSION}

Based on the results of research and discussion of the data that has been done, it can take several conclusions, among others:

- The longer time the thicker layer of coating the magnetite $\left(\mathrm{Fe}_{3} \mathrm{O}_{4}\right)$ which is formed on the metal substrate and smallest number of gloss.

- The higher the temperature, the more thick layer of magnetite $\left(\mathrm{Fe}_{3} \mathrm{O}_{4}\right)$ which is formed on the metal substrate and the smallest number of gloss.

\section{REFERENCES}

1. Nasser Kanani, Electroplating Basic Principles, Processes, and Practice, Elsevier, Germany, 2004.

2. Arab, N., and Soltani. 2009. A Study of Coating Process of Cast Iron Blackening. Iran: Journal of Applied Chemical Research, 13-23.
3. Schwartz, Mel. 2002. Encyclopedia and Handbook of Materials, Parts and Finishes Second Edition. Florida: CRC Press LLC.

4. Ferreira, Essential, et al. 2001. Influence of the Temperature of Film Formation on the Electronic Structure of Oxide Films Formed on Stainless steel 304, Eletrochimica Acta 46, 3767-3776.

5. Lebbai, Kim, et al. 2003. Optimization of Black Oxide Coating Thickness as an Adhesion Promoter for Copper Substrate-Integrated Circuit in Plastic Packages. Hongkong: Journal of Electronic Materials, Vol. 32, No. 6.

6. Lundberg, Weitzberg, et al. 2008. The Nitrate-Nitrite-Nitric Oxide Pathway In Physiology And Therapeutics. Nat. Rev. Drug Discov. 7, 156-67.

7. Zhu, H., Cao, F., Zuo, D., Zhu, L., Jin, D., Yao, K (2008) “A New Hydrothermal Blackening Technology for $\mathrm{Fe}_{3} \mathrm{O}_{4}$ Coatings of Carbon Steel" Applied Surface Science 254, 5905-5909.

8. J. Weber, T.Biestek, Electrolytic and Chemical Conversion Coatings, Portcullis, USA, (1976).

9. A. M. Khan Hezaveh, Comprehensive Dictionary of Metals Coatings, Atlas, IRAN (1988).

10. HE Xin-Kuai, Chen Bai-Zhen, LI Xiao-Dong, J. Cent. South Univ. Technol., 13, 135, (2006).

11. R. Martin Jr., Blackening of metals, Available online in: http://www.blackcote.com

12. Kirk, R.E. and Othmer, V.R. 1993. Encyclopedia of Chemical Technology, vol.5 Carbon \& Graphite Fibers to C1-Chlorocarbons, 4th Edition. New York : John Wiley \& Sons Inc.

13. Perry, Robert H. 1997. Perry's Chemical Engineers Handbook Seventh Edition. New York: The McGraw-Hill Companies, Inc.

14. D.J. O'Connor, B.A. Sexton, and R.St.C. Smart, editors, Surface Analysis Methods in Materials Science (Berlin: Springer-Verlag, 1992), pp. 203-248.

15. M. John, Basic Corrosion and Oxidation, Ellis Horwood, USA (1986).

16. P. H. Setyarini, F. Gapsari, Purnomo, Study of Predicting Corrosion on aa 6063-t5 using eis method in different corrosion media, International Journal of Mechanical Engineering and Technology, Vol. 9, pp. 507-514, 2018

17. F. Gapsari, R. Soenoko, A. Suprapto, W. Suprapto "Effect of Organics Corrosion Inhibitors on the Corrosion of $304 \mathrm{SS}$ in $3.5 \% \mathrm{NaCl}$," Int. R. of Mech. Eng., 10 (2016).

18. F. Gapsari, R. Soenoko, A. Suprapto, W. Suprapto, "Bee wax propolis extract as eco-friendly corrosion inhibitors for 304SS in sulfuric acid," Int J. Corros. 1(2015)

19. R. Zhulhijah, S. Machmudah, Wahyudiono, H. Setyawan, "The formation of the steel film by hydothermal electrolysis for corrosion protection", Industrial Research Workshop And National Seminar, ISBN: 978-979-3541-25-9, (2012).

\section{AUTHORS PROFILE}

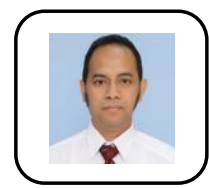

Arya Mahendra Sakti, is a lecturer and vice head of department in the department of mechanical engineering, State University of Surabaya-Indonesia. He studied master degree of mechanical engineering in the Institute of Technology Sepuluh Nopember. Along his carrier, he is in charge as junior editor of Otopro (journal of department), also assessor for Vocational Senior High School in East Java Province, Indonesia. He was choosen as one of the participant of the bridging program (February 2013-June 2013) which was held by The ministry of research and higher education of indonesia in National Taiwan University of Science and Technology, Taiwan. In 2017, he was doing research about nickel-chrom coating on metal, which is focus on the effect of the distance of anode-cathode and the dipping time on the thickness of its coating. Meanwhile in 2018, he presented his research at International Conference on Mechanical Engineering Research and Application (ICOMERA), with the title of "The Effect Of Variables Process On Thickness And Glossiness Of Metal Coating Workpiece On The Nickel-Khrom Metal Coating Process". In that year, he was also concern on the research in education. In which the result was presented at national conference. The title is The application of practice learning media based on enterpreuner in the coating engineering course. The last research he conducted is "The design of Blackening equipment for metal coating procees" and "the design of metal coating equipment for student practice in metal coating laboratory.

He wrote one book: Modul of manufacturing process $1^{\text {st }}$, in 2014 . His orchid account is http://orcid.org/0000-0001-9254-2365. 


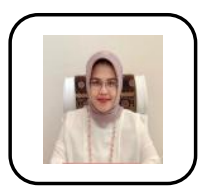

Aisyah Endah Palupi, is a Professor of engineering at the State University of Surabaya-Indonesia. She was an Indonesian Education and Culture Attache in Manila, Philippines (2014-2015) and in Singapore (2015-2018), as well as an expert staff of vice rector of the State University of Surabaya for Student Affairs and Academic (2013-2014). She got PhD from Institute of Technology Sepuluh Nopember. For the time being, she serves as editorial board member of Teknika Jurnal, Faculty of Engineering State University of Surabaya, senior editor of Otopro Journal, Machine Engineering Department, Faculty of Engineering State University of Surabaya, an Assessor for Vocational Senior High School in East Java Province, Indonesia. She presented as a keynote speaker at international conference in The $11^{\text {th }}$ International Conference on Educational Research (ICER 2018): Innovation for Capacity Building and Networking, with her education research entitled "Strategy to Develop the Ability of Creative Thinking Using Problem-Based Learning Model in Light Vehicle Engineering Competences of Vocational Education". The last research that finished was entitled "Effect of electrolytes on the formation of graphene via electrochemical exfoliation process using spent zinc-carbon as graphene source". She also participated in Academic Recharging (PAR) Program Type C in Universität Duisburg Essen, Germany, (October 2009 - February 2010). She also one of the best participant on Workshop on Membrane Technology for Water and Wastewater Treatment by ITS Surabaya collaborated with Universiti Teknologi Malaysia (UTM), 2004. She wrote several books, ie: Buku Ajar Teknik Korosi (Corossion Technique Course Book), 2014; Petunjuk Praktikum Elektroplating (Practical Guide for Electroplatting); Buku Panduan bagi Pelajar Indonesia untuk Belajar di Filipina (Guide Book for Indonesian Students to Study in Philippines), 2016; Sekilas Pendidikan di Singapura (A Glance Overview of Education in Singapore), 2018; and Rising 50 Goes to Campus, 2018.

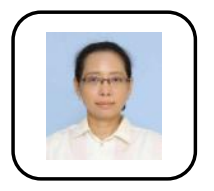

Dyah Riandadari, is a lecturer at the State University of Surabaya (UNESA)-Indonesia since 2008. She is a head of the library in Department of Mechanical Engineering Unesa. She completed her bachelor degree program at the Institute of Technology Sepuluh Nopember (ITS),

Surabaya-Indonesia in Engineering Physics and also master degree program at the Institute of Technology Sepuluh Nopember, but in the different field, that is Industrial Engineering. She has taught for many courses, those are Engineering Physics 1, Applied Physics, Engineering Physics 2, Health and Safety (K3), Industrial Management, and Entrepreneurship. Journal publication which she was involved, are: "The Effect of Process Variables On Thickness and Glossiness of Metal Coating workpiece On the Nickel-Chromium Metal Coating Process" (2018), "Analysis of Anode-Cathode Distance and Old Time Against Immersion Coating Process Coating Thickness Metal Nickel-Chrome" (2017), and "The Application of Practice Learning Media Based on Entrepreneur in the Coating Engineering Course" (2017). The last research she conducted is "The Design of Blackening Equipment for Metal Coating Procees" She was involved wrote several books, ie: Buku Ajar Fisika Teknik I (Engineering Physics Textbooks I), 2019; Kewirausahaan (Entrepreneurship), 2016; and Modul Teknik Industri (Teaching Module of Industrial Management), 2009. She was bridging program participant for Indonesia prospective doctorate students at the National Kaohsiung University of Applied Sciences, Kaohsiung-Taiwan (February 2013-June 2013). 